\title{
Tubal Ektopik Gebeliklerde Metotreksat Tedavi Başarısını Öngörmede Nötrofil-lenfosit Oranı ve Platelet-lenfosit Oranı
}

\section{Neutrophil-lymphocyte Ratio and Platelet-lymphocyte Ratio on the Prediction of Methotrexate Treatment Success in Tubal Ectopic Pregnancy}

\author{
Hatice Yılmaz Doğru', Çiğdem Kunt İşgüder ${ }^{1}$, Asker Zeki Özsoy', İlhan Bahri Delibas', \\ Bülent Cakmak', Akgul Arici ${ }^{2}$
}

${ }^{1}$ Obstetrics and Gynecology, Gaziosmanpasa University, Tokat, Turkey.

2 Pathology, Gaziosmanpasa University, Tokat, Turkey

\section{ÖZET}

Giriş: Ektopik gebelik tüm gebeliklerin \%2'sini oluşturmakta, aynı zamanda vakaların \%95'ten fazlası fallop tüplerinde lokalizedir. $\mathrm{Bu}$ çalışmada; tubal gebeliklerde metotreksat tedavi başarısını değerlendirmek, ve nötrofil-lenfosit oranı, trombosit-lenfosit oranı ve tubal ektopik gebelik rüptürü arasındaki ilişkiyi incelemek amaçlanmıştır.

Gereç ve Yöntem: Bu retrospektif çalışma, Gaziosmanpasa Üniversitesi, Kadın Hastalıkları ve Doğum Anabilim Dalı’nda 2012 ve 2014 yılları arasında yapılmıştır. Veriler Statistical Package for Social Sciences (SPSS) yazılım versiyonu 20.0 (SPSS Inc., Chicago, IL) ile analiz edildi. Tüm karşılaştırmalarda çift taraflı $p$ değeri $<0.05$ olarak kabul edildi.

Bulgular: Nötrofil-lenfosit oranı rüptüre olup cerrahi tedavi geçirmiş hastalarda rüptüre olmayıp metotreksat tedavisi alan hastalara göre yüksek saptandı ( $p=0.009$ ). Beraberinde, nötrofil-lenfosit oranı metotreksat tedavisine yanıt veren hastalarda yanıt vermeyenlere göre yüksek bulundu $(p=0.027)$.

Sonuç: Ektopik gebelik kese çapı ve B-HCG değeri yanında, nötrofilIenfosit oranı ve platelet-lenfosit oranı metotreksat tedavisinin başarısını öngörmede yararlı belirteçler olabilirler.

Anahtar Kelimeler: Gebelik, Ektopik, Metotreksat, Nötrofil, Lenfosit, Plateletler

\section{ABSTRACT}

Objective: A \%2 of all pregnancies composed of ectopic pregnancy, further more than $95 \%$ of cases localized on the fallopian tubes. The aim of this study is to assess the success of metotrexate treatment on tubal pregnancy, and the relation between the neutrophil-lymphocyte ratio and thrombocyte-lymphocyte ratio, and tubal ectopic pregnancy rupture.

Materials and Methods: This retrospective study was conducted in Gaziosmanpasa University, Department of Obstetrics and Gynecology between 2012 and 2014. Patients with a diagnosis of tubal ectopic pregnancy whose admitted to the Department of Obstetrics and Gynecology were enrolled in the study. The data was analyzed using the Statistical Package for Social Sciences (SPSS) software version 20 (SPSS Inc., Chicago, IL). A two-tailed $\mathrm{p}$ value $<0.05$ was regarded as statistically significant for all comparisons.

Results: The neurophil-lymphocyte ratio was significantly higher in ruptured surgical treated patients compared to unrupturedmethotrexate treated patients $(p=0.009)$. Additionally, the neurophillymphocyte ratio was significantly higher in methotrexate responsive patients than in non-responsive ones ( $p=0.027)$.

Conclusion: Beside B-HCG level and ectopic pregnancy sac diameter, neutrophil-lymphocyte ratio and platelet-lymphocyte ratio may be useful tools to predict the success of the methotrexate therapy.

Keywords: Pregnancy, Ectopic, Methotrexate, Neutrophils, Lymphocytes, Blood Platelets 


\section{INTRODUCTION}

The implantation of fertilized ovum to another place except uterine cavity is defined as ectopic pregnancy [1-3]. Currently, \%2 of all pregnancies composed of ectopic pregnancy, further more than $95 \%$ of cases localized on the fallopian tubes. Despite advances in diagnosis and treatment, it has been an important cause of maternal death associated with pregnancy in the first trimester [4]. The main risk factors of ectopic pregnancy are tubal damage, previous ectopic pregnancies and adjuvant fertility technics [3]. The pathogenesis depends on changes occurred in micro environment of fallopian tubes leading early implantation of fertilized ovum and ciliary dysfunction [5]. Clinically, one-third of patients show no symptoms. In addition, a positive pregnancy test with syncope or hemorrhagic shock may be the findings of a ruptured ectopic pregnancy $[6,7]$. Medical treatment with methotrexate in unruptured cases is an effective and safe alternative method to surgery $[8,9]$.

A current study have emphasized the role of platelets and platelet derived agents in thrombosis, angiogenesis, inflammation and immunity [10]. In ectopic pregnancy, inflammatory cytokine levels increase in both inflammation site and systemic circulation [5]. Similarly with the activation of signaling pathways, such leukocytes guided by cytokines, chemokines and integrins to the inflammatory site, the embryo is directed to the implantation field [11].

Furthermore, hemogram parameters including immune system items have an important role in the diagnosis of several disorders. Lymphocytes, leucocytes and thrombocytes, hold significant roles in controlling of inflammation [12-14]. Recently, the ratio of neutrophil to lymphocyte count and platelet to lymphocyte have been used as a biomarker of systemic inflammation, and evaluated in various malignancy studies [15-17].

The aim of this study is to assess the success of MTX treatment on tubal pregnancy, and the relation between the neutrophil-lymphocyte ratio and thrombocyte-lymphocyte ratio, and tubal ectopic pregnancy rupture.

\section{MATERIALS AND METHODS}

This retrospective study was conducted in Gaziosmanpasa University, Department of Obstetrics and Gynecology between 2012 and 2014. Patients with a diagnosis of tubal ectopic pregnancy whose admitted to the Department of Obstetrics and Gynecology were enrolled in the study. The following parameters were the exclusion criteria: connective tissue diseases such as systemic lupus erythematosus, rheumatoid arthritis, chronic inflammatory diseases such as vasculitis, renal or hepatic failure, chronic hypertensive disease, diabetes mellitus, a previous history of myocardial infarction and thrombosis.

The condition of tubal ectopic pregnancy either ruptured or treated with methotrexate, maternal age, $\beta$-HCG level, ectopic pregnancy sac diameter, neutrophil-lymphocyte ratio, and platelet-lymphocyte ratio were obtained from the patient records. The hemogram parameters after admission were used to calculate the neutrophil-lymphocyte ratio, and plateletlymphocyte ratio. The success of methotrexate treatment was defined as the decrease in $\beta$-HCG level more than $15 \%$ between the $4^{\text {th }}$ and $7^{\text {th }}$ days. In addition, failure in treatment was described as the requirement of an additional methotrexate dose or an operation.

Qualitative data was presented as number and percentage, since qualitative data as mean and standard deviation. Mann Whitney $U$ test was used to compare for all groups. The data was analyzed using the Statistical Package for Social Sciences (SPSS) software version 20 (SPSS Inc., Chicago, IL). A two-tailed $p$ value $<0.05$ was regarded as statistically significant for all comparisons.

\section{RESULTS}

A total of 39 patient records were included. The mean age was $31,48 \pm 4,49$. The median value of gravida was 3 (minimum $=1$, maximum $=5$ ), and parity was 1 (minimum $=1$, maximum $=5)$. Since 16 patients were operated due to ruptured tubal ectopic pregnancy, a sum of 23 cases with unruptured tubal ectopic pregnancy 
were treated with methotrexate. In nine cases the methotrexate treatment was successful, while in 14 cases was not.

The $\beta$ HCG levels, the mean diameters of ectopic pregnancy sac, neutrophil-lymphocyte ratio, and platelet-lymphocyte ratio of ruptured and unruptured ectopic pregnancy cases were presented in Table 1. The neurophil-lymphocyte ratio was significantly higher in ruptured surgical treated patients compared to unrupturedmethotrexate treated patients $(p=0.009)$.

Table 1. Characteristics of ruptured and unruptured patients

\begin{tabular}{|l|c|c|c|}
\hline & UR-MTP & R-STP & p \\
\hline & Mean \pm SD & Mean \pm SD & \\
\hline $\boldsymbol{\beta}$-HCG & $1071,08 \pm 763,56$ & $3368,12 \pm 3121,93$ & $\mathbf{0 , 0 0 3 *}$ \\
\hline $\begin{array}{l}\text { Sac } \\
\text { Diameter } \\
\text { (cm) }\end{array}$ & $2,06 \pm 0,74$ & $2,41 \pm 1,10$ & 0,373 \\
\hline PLR & $125,28 \pm 43,64$ & $143,76 \pm 90,31$ & $>0,05$ \\
\hline NLR & $2,79 \pm 1,98$ & $5,43 \pm 3,40$ & $\mathbf{0 , 0 0 9 *}$ \\
\hline
\end{tabular}

$* p<0.05$

PLR, platelet-lymphocyte ratio; NLR, neutrophil-lymphocyte ratio; UR-MTP, unruptured-methotrexate treated patients; R-STP, ruptured surgical treated patients

The $\beta$-HCG levels, the mean diameters of ectopic pregnancy sac, neutrophil-lymphocyte ratio, and platelet-lymphocyte ratio of success and failed methotrexate treated ectopic pregnancy cases were presented in Table 2 . The neurophil-lymphocyte ratio was significantly higher in methotrexate responsive patients than in non-responsive ones ( $p=0.027)$.

Table 2. Methotrexate treated patients.

\begin{tabular}{|l|c|c|c|}
\hline & Responsive & Non-responsive & p \\
\hline & Mean \pm SD & Mean \pm SD & \\
\hline $\boldsymbol{\beta}$-HCG & $1299,71 \pm 824,15$ & $715,44 \pm 515,58$ & 0,101 \\
\hline $\begin{array}{l}\text { Sac } \\
\text { Diameter } \\
\text { (cm) }\end{array}$ & $2,26 \pm 0,80$ & $1,76 \pm 0,53$ & 0,216 \\
\hline PLR & $123,02 \pm 49,82$ & $128,80 \pm 34,37$ & 0,488 \\
\hline NLR & $3,30 \pm 2,35$ & $2,00 \pm 0,83$ & $\mathbf{0 , 0 2 7}$ \\
\hline
\end{tabular}

$*_{p}<0.05$

PLR, platelet-lymphocyte ratio; NLR, neutrophil-lymphocyte ratio.

\section{DISCUSSION}

The present study revealed that the NLR was higher in ruptured tubal ectopic pregnancy than methotrexate treated patients. In addition, the NLR was higher in failure of methotrexate treated patients compared to successfully treated with methotrexate.

Ectopic pregnancy is a combination of tubal micro environmental changes including impaired tubal transportation of fertilized ovum and early implantation to the fallopian tube [5]. Inflammation in fallopian tube due to infection or smoking leads to ectopic pregnancy by effecting the smooth muscle activity and ciliary movement $[8,9]$.

Hemogram parameters including immune system elements has a significant role on the assessment and diagnosis of a variety of diseases [12-14]. Recently, neutrophil-lymphocyte ratio shows a remarkable factor as an inflammatory marker, which has been currently used as a prognostic tool for cardiovascular diseases, cancer and several inflammatory disorders [18-21]. Neutrophils are the most prominent leukocytes those leading to inflammation and tissue injury in patients with ulcerative colitis [22]. In histopathological evaluation, it is shown that neutrophil accumulation and abcess formation are occured in the intestinal crypts at the apical epithelial surface in patients with ulcerative colitis [23]. In contrast, the lymphocyte functions shows abnormalities on both peripheral blood and mucosal level in patients with inflammatory bowel disease. According to these outcomes, Torun et al. reported that NLR were significantly rises in active ulcerative colitis [24].

In relation, Celikbilek et al. demonstrated that NLR has a close relationship with active ulcerative colitis [25]. The present study revealed that the NLR is increased during an impairment in clinical condition or responsiveness to medical treatment. This result suggested that NLR can predict the rupture risk of ectopic pregnancy and responsiveness to medical therapy.

Furthermore, the clinical use of methotrexate treatment is first established by Tanaka et al. in 1980 [26]. A study conducted by Menon et al. on 
503 patients showed that B-HCG level over 5000 $\mathrm{mIU} / \mathrm{ml}$ may associated with a lower success rate of treatment [27]. A recent study by Sagiv et al. on 238 patients treated with methotrexate demonstrated that a B-HCG level of $>2000$ mIU/ $\mathrm{ml}$ had a 4.5 fold failure risk in treatment with treatment [28]. In the present study, the B-HCG level was higher in patients with ruptured tubal ectopic pregnancy compared to metotrexate treated cases.

Moreover, there has been contraversy on the adequate sac diameter of ectopic pregnancy for medical treatment. Many investigators reported a higher success in a sac diameter up to $3,5 \mathrm{~cm}$, where the others indicated larger than $3,5 \mathrm{~cm}$ [29-31].

In addition, Feras et al. revealed that no association was existed between response to methotrexate treatment and ectopic pregnancy sac diameter [32]. Similar with the latter study, the current study showed no relation between response to medical treatment and ectopic pregnancy sac diameter.

Platelets are the natural sources of tissue regeneration, angiogenesis and growth factors those are crucial in inflammation [33]. Whether ruptured or not, various platelet indexes such as MPV and PDW can be altered associated with the inflammation and tubal micro environmental changes [34]. In this context, Artunc et al. reported that MPV values were lower in tubal pregnancy than in intrauterine pregnancies as well as in ruptured tubal pregnancies [35]. The PLR values were similar between methotrexate treated patients and ruptured ectopic pregnancy patients in the current study. Further, the PLR values showed no difference between the methotrexate responsive and non-responsive patients.

In conclusion, late diagnosis of ectopic pregnancy resulting of tubal inflammation is a life threatening condition. Medical treatment can be an alternative therapy to surgery. The present study revealed that beside B-HCG level and ectopic pregnancy sac diameter, NLR and PLR may be useful tools to predict the success of the methotrexate therapy. However, further studies including larger populations are required to elucidate the effectiveness.

\section{ACKNOWLEDGEMENTS}

We thank to Dr Serkan Dogru for his valuable contribution to the study.

\section{COMPETING INTERESTS}

None declared.

\section{REFERENCES}

1. Walker JJ. Ectopic pregnancy. Clin Obstet Gynecol 2007; 50: 89-99.

2. Della-Giustina D, Denny M. Ectopic pregnancy. Emerg Med Clin 2003; 21: 565-84.

3. Varma R, Gupta J. Tubal ectopic pregnancy. BMJ Clin Evid 2009; 1406: PMC2907783.

4. 4. Fylstra DL. Tubal pregnancy: a review of current diagnosis and treatment. Obstet Gynecol Surv 1998; 53: 320-28.

5. Shaw JLV, Dey SK, Critchley HOD, Horn AW. Current knowledge of the aetiology of human tubal ectopic pregnancy. Hum Reprod Update 2010; 16: 432- 44.

6. Tay JI, Moore J, Walke JJ. Ectopic pregnancy. BMJ 2000; 32: 916-19.

7. Kaplan BC, Dart RG, Moskos M, et al. Ectopic pregnancy: prospective study with improved diagnostic accuracy. Ann Emerg Med 1996; 28: 10-17.

8. Barnhardt KT. Ectopic pregnancy. N Engl J Med 2009; 361: 379-87.

9. Stovall TG, Ling FW. Single-dose methotrexate: an expanded clinical trial. Am J Obstet Gynecol 1993;168: 1759-65.

10. Wagner DD, Burger PC. Platelets in inflammation and thrombosis. Arterioscler Thromb Vasc Biol 2003; 23: 2131-37.

11. Dominguez F, Yanez-Mo M, Sanchez-Madrid F, Simon C. Embryonic implantation and leukocyte transendothelial migration: different processes with similar players? FASEB J 2005; 19: 1056-60.

12. Yao Y, Simard AR, Shi FD, Hao J. IL-10-producing lymphocytes in inflammatory disease. Int Rev Immunol 2013; 32: 324-36. 
13. Scapini $P$, Cassatella MA. Social networking of human neutrophils within the immune system. Blood 2014; 124: 710-9.

14. Choi JL, Li S, Han JY. Platelet function tests: a review of progresses in clinical application. Biomed Res Int 2014; 456-569.

15. Templeton AJ, McNamara MG, Seruga B, et al. Prognostic role of neutrophil-to-lymphocyte ratio in solid tumors: a systematic review and meta-analysis. J Natl Cancer Inst 2014; 29: 106.

16. Templeton AJ, Ace O, McNamara MG et al. Prognostic a systematic review and meta-analysis. Canc Epidemiol Biomarkers Prev 2014; 23: 1204-12.

17. Sahin S, Sarıkaya S, Alcelik A, et al. Neutrophil to lymphocyte ratio is a useful predictor of atrial fibrillation in patients with diabetes mellitus. Acta Medica Mediterranea 2013; 29: 847-51

18. Ergelen M, Uyarel H, Altay S, Kul S, Ayhan E, Isik T, et al. Predictive value of elevated neutrophil to lymphocyte ratio in patients undergoing primary angioplasty for ST-segment elevation myocardial infarction. Clin Appl Thromb Hemost 2013; 228: 203-10.

19. Gul M, Uyarel H, Ergelen M, Ugur M, Isik T, Ayhan E et al. Predictive value of neutrophil to lymphocyte ratio in clinical outcomes of non-ST elevation myocardial infarction and unstable angina pectoris: A 3-year followup. Clin Appl Thromb Hemost 2014; 20: 378-84.

20. Cedres S, Torrejon D, Martinez A, Martinez P, Navarro $A$, Zamora E, et al. Neutrophil to lymphocyte ratio (NLR) as an indicator of poor prognosis in stage IV non-small cell lung cancer. Clin Transl Oncol 2012; 14: 864-69.

21. Li MX, Liu XM, Zhang XF, Zhang JF, Wang WL, Zhu Y, et al. Prognostic role of neutrophil-to-lymphocyte ratio in colorectal cancer: A systematic review and metaanalysis. Int J Cancer 2014; 134: 2403-13.

22. Hermanowicz A, Gibson PR, Jewell DP. The role of phagocytes in inflammatory bowel disease. Clin Sci (Lond) 1985; 69: 241-49.

23. Gewirtz AT, Liu Y, Sitaraman SV, Madara JL. Intestinal epithelial pathobiology: past, present and future. Best Pract Res Clin Gastroenterol 2002; 16: 851-67.

24. Torun S, Tunc BD, Suvaka B, Yildiz H, Tas A, Sayilir A, et al. Assessment of neutrophil-lymphocyte ratio in ulcerative colitis: A promising marker in predicting disease severity. Clin Res Hepatol Gastroenterol 2012; 36: 491-497.

25. Celikbilek M, Dogan S, Ozbakır O, Zararsız G, Hamit Kucuk H, Gursoy S, et al. Neutrophil-Lymphocyte Ratio as a Predictor of Disease Severityin Ulcerative Colitis. J Clin Lab Anal 2013; 27: 72-76.

26. Hajenius PJ, Mol F, Mol BW, Bossuyt PM, Ankum WM, van derVeen F. Interventions for tubal ectopic pregnancy. Cochrane Database Syst Rev 2007; 24: CD000324.

27. Menon S, Colins J, Barnhart KT. Establishing a human chorionic gonadotropin cutoff to guide methotrexate treatment of ectopic pregnancy: a systematic review. Fertil Steril 2007; 87: 481-484.

28. Sacher B, Keidar R, Golan A. The optimal cutoff serum level of human chorionic gonadotropin for efficacy of methotrexate treatment in women with extrauterine pregnancy. Int J Gynaecol Obstet 2012; 116: 101-04.

29. American College of Obstetricians and Gynecologists. ACOG Practice Bulletin No. 94: Medical management of ectopic pregnancy. Obstet Gynecol 2008; 111: 1479-85.

30. Hajenius PJ, Mol F, Mol BWJ, Bossuyt PM, Ankum WM, van der Veen F. Interventions for tubal ectopic pregnancy. Cochrane Database Syst Rev 2000; CD000324.

31. Practice Committee of American Society for Reproductive Medicine. Medical treatment of ectopic pregnancy: a committee opinion. Fertil Steril 2013; 100: 638-44. 32. Sendy F, AlShehri E, AlAjmi A, Bamanie E, Appani S, Shams T. Failure Rate of Single Dose Methotrexate in Managment of Ectopic Pregnancy 2015; Article ID 902426.

32. Vagdatli E, Gounari E, Lazaridou E. Platelet distribution width: a simple, practical and specific marker of activation of coagulation. Hippokratia 2010; 14: 28-3.

33. Turgut A, Sak ME, Ozler A. Alterations of peripheral blood cells in tubal ectopic pregnancy. Ginekol Pol 2013; 84: 193-196.

34. Artunc Ulkumen B, Gursoy Pala H, Calik E, Oruc Koltan S. Can mean platelet volume and platelet distrubition width be possible markers for ectopic pregnancy and tubal rupture? (MPV and PDW in ectopic pregnancy). Pak J Med 2014; 30: 252-55. 